\title{
The case of the gene
}

\author{
Postgenomics between modernity and postmodernity
}

\author{
Laurence Perbal
}

$\mathrm{T}$ he history of modernity is a story about humans emancipating themselves from prejudice and superstition through reason and science. Scientific research has been a major driving force of progress for human civilization since the industrial revolution in the mid- $18^{\text {th }}$ century. During the past 250 years, humans have rapidly increased their use of science, as a tool not only to understand and shape their environment, but also to improve themselves with better health care and longer, more comfortable lives. Unfortunately, the application of science has not always been appropriate: Darwin's theory of natural selection was applied to social policies in the form of eugenics from the early $19^{\text {th }}$ century until the second half of the $20^{\text {th }}$ century. In this period, eugenics remained a popular ideology and, as a consequence, genetics was a popular science. It was also a period of significant human migration that increased racial diversity in Western nations, with resulting concerns about racial purity. Naturalism and social Darwinism were very popular throughout, while industrialization led to massive urbanization and increasing pauperism. Politically, it was a time of interventionist policies, such as the so-called Progressive Era in the USA that led to drastic social and political change.

\section{"No more divine designer, no more life force is needed; life is determined by a genetic program and evolves as a result of chance-or human choice-and selection"}

Eugenics gained scientific legitimacy in the early $20^{\text {th }}$ century owing to Mendelian genetics, which offered a rational, scientific theory to understand, predict, and control heredity and thereby the characteristics of future generations. As pauperism, criminality, and "feeblemindedness" were thought to be genetically determined, eugenics offered a tool to eliminate these undesirable traits from the human population.

Of course, the idea of a single and universal definition of "the gene" is currently disappearing together with the idea from the early days of genetics that one or a few genes are the ultimate determinants of phenotypic traits. Our current understanding of genotype/phenotype relationships is now far more nuanced and complex. Genetics has evolved from Mendelian inheritance to genomics, and epigenetics to postgenomics. Nevertheless, the history of eugenics and the original concept of "the gene" sheds light on the history of genetics itself. The story is exemplary of the dynamic status of scientific theories: Definitions and epistemologies come and go, often questioning and correcting one another.

$\mathrm{T}$ he history of genetics begins with the rediscovery of Mendel's laws of inheritance in 1901 by Hugo de Vries, Carl Correns, and Erich von Tschermak. Mendel assumed the existence of units of heredity that are passed on between generations according to mathematical laws. Mendel's unknown factors of heredity were given the name "gene" in 1909. In 1910, the American scientist Thomas Morgan proposed that chromosomes are the carriers of Mendelian hereditary factors and that those factors segregate during the production of germ cells and recombine during sexual reproduction. Morgan developed a phenomenal and mutationist explanation of genes: After having identified a mutation, it should be possible to localize the mutated gene on the chromosome. Because Morgan and his colleagues were unaware of the material nature of genes, their approach did not start from the genotype and proceed to the phenotype, but followed the reverse direction. This is called the functionalist approach, since the gene is defined by its phenotypic function. The simplistic expression "a gene for" is heir to this tradition.

"Once [...] the meanings have been clarified, the gene becomes a pragmatic tool that enables different experimental systems and research programs"

In the 1940s, advances in biochemistry and molecular biology finally made it possible to explain the material nature of genes. George Beadle and Edward Tatum demonstrated the link between genes and enzymes in 1941, thus offering a new functionalist definition of the gene: It is enzymatic and no longer mutationist. In 1944, Oswald Avery, Colin MacLeod, and Maclyn McCarty discovered that DNA is the carrier of heredity. In 1953, James Watson and Francis Crick resolved the double helical structure of DNA. French microbiologists François Jacob, André Lwoff, and Jacques Monod showed that DNA is structured in codons that determine the synthesis of proteins from individual amino acids. In reference to this code, Jacob, Monod, and Ernst Mayr, in 1961, advanced the genocentric hypothesis that embryonic development is the result of a "genetic program". Finally, between 1961 and 1965, the mechanism that turns information from DNA into protein was determined by explaining the roles of 

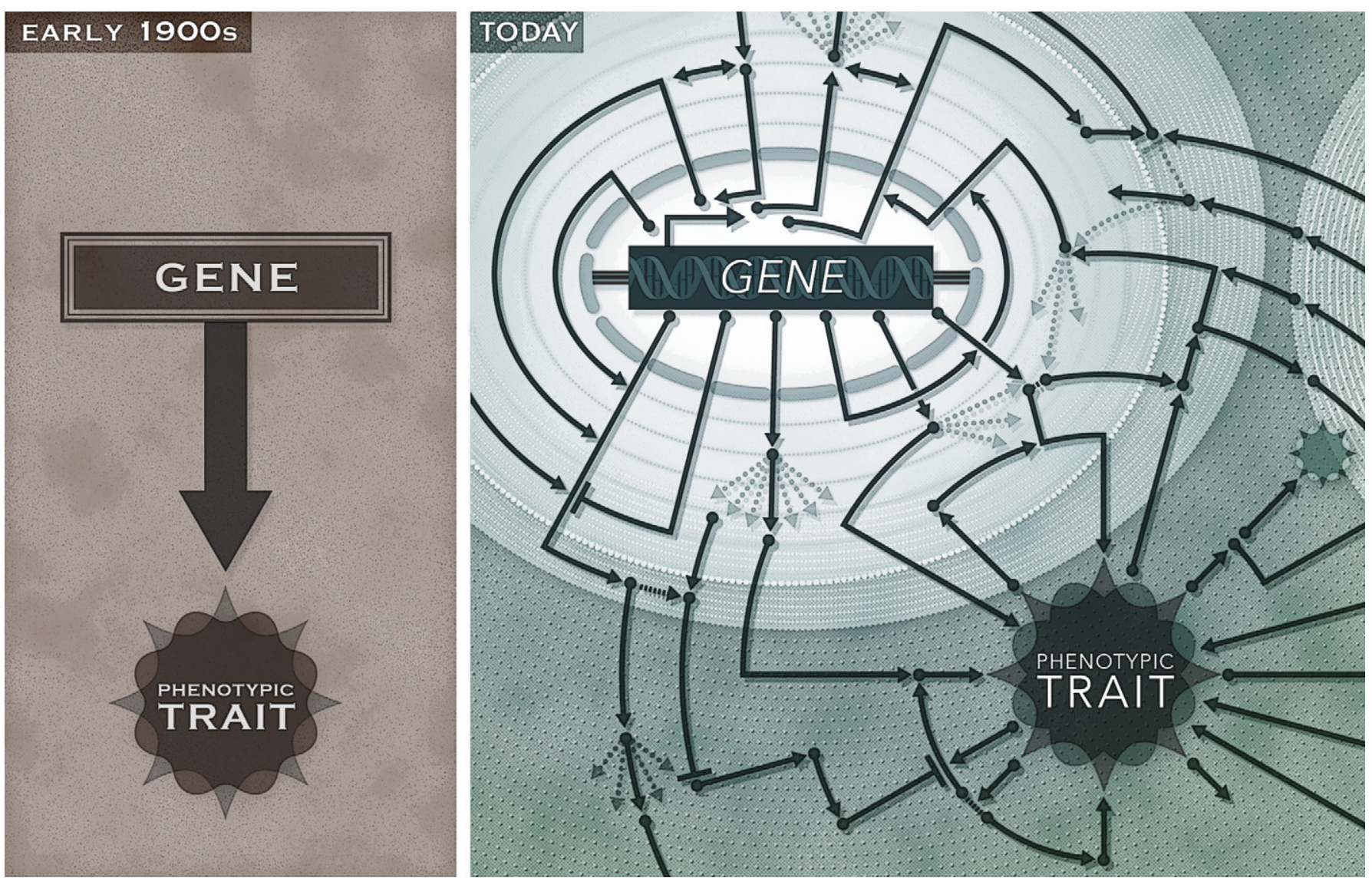

transfer and messenger RNA. By the 1950s, the gene had therefore come to be seen as a molecular hereditary entity, defined as a DNA segment that encodes a chain of amino acids involved in the formation of a protein.

Ever since the concept of the gene was introduced in the early 1900s, the successive functional and structural definitions have evolved dialectically to an ever-deeper level of chemical analysis [1]. The gene was first defined as a Mendelian trait, and then, it became a locus and then linked to a protein and, finally, to elements of proteins (amino acids). This development reflects the desire to focus the gene's definitions on a unique entity [2]: a phenotype, a mutation, a protein, an enzyme, a nucleotide sequence, and so on. Yet, despite the progress made in the molecular understanding of genes, functionalist expressions- "genes for"-have never stopped multiplying: the gene "for" cancer, or schizophrenia, diabetes, intelligence, homosexuality, crime depression, and so on.

In the 1990s, it became possible to sequence whole genomes, which gave rise to genomics. Rather than analyzing the sequence and function of individual genes, genomics tries to identify and understand both individual genes and their interaction with each other. Together with transcriptomics, proteomics, metabolomics, and bioinformatics, genomics spawned systems biology, which aims to understand and model the interaction of many components in the cell, not just genes, in an effort to explain how genetic information translates into phenotypic traits.

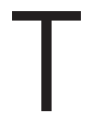

he enormous advances in molecular biology since the early 1900s have further reinforced modern rationalism, because they offer a rational alternative to the vitalistic hypothesis, which implies that a life force is necessary to animate organic matter. In fact, we have not needed the "élan vital" since the synthesis of urea demonstrated that organic compounds obey the same physical and chemical laws as inorganic compounds. Moreover, as Monod said, "ce qui est vrai pour la bactérie est vrai pour l'éléphant”, which means that all living beings obey the same natural laws. No more divine designer, no more life force is needed; life is determined by a genetic program and evolves as a result of chance-or human choice-and selection.

More generally, modern biology explains the natural world through the laws of evolution and genetics. For example, homosexuality, which appears not to make sense for animals from a reproductive point of view, might instead have important altruistic potential, thus explaining its evolution, and consciousness might have evolved because it provides distinct survival advantages. The Human Genome Project symbolizes this genocentric narrative of using the power of genetics to better understand human nature. The director of the HGP, Francis Collins, explained that sequencing the human genome is "the most important and the most significant project that humankind has ever mounted" [3]. John Sulston, former President of the Sanger Center, was quoted in the UK newspaper The Observer: "Think of the human genome as the Book of Life. We are about to read the first chapter, as important an accomplishment as discovering the Earth goes round the sun or that we are descended from apes" [4]. 
$\mathrm{H}$ owever, things are much more complex than genocentrism implies. Living organisms are not only controlled by their genetic program-by which segments of DNA are translated into proteins-but are in fact self-organizing systems that involve countless interactions between proteins, nucleic acids, and metabolites within a complex structure. The word "postgenomics" to describe this concept reflects the fact that geneticists and philosophers alike acknowledge that current genetic epistemology has entered the postgenomic era [5]. As the name suggests, it inherits from the genomic era and aims to exceed its genocentric limits.

According to the postgenomic concept, the gene is no longer interpreted as a unique functional or molecular entity. Indeed, through alternative splicing, most genes can code for many different proteins; moreover, the messenger RNA and the transcribed protein can be further modified to increase the variety of protein products. The regulation of transcription and translation is also controlled by a plethora of proteins, RNA molecules, DNA segments, and chemical modification of DNA. In eukaryotes, many regulatory regions may be located far away from the coding sequence and may also be involved in the regulation of more than one gene; mechanisms that control transcription therefore involve the three-dimensional structure of DNA. The result of this bewildering complexity is that the number of "functional units" is much greater than the number of coding sequences. Even the concept of DNA as the unique carrier of heredity has been challenged by observations of epigenetic inheritance: the transmission of information about environmental factors from one generation to the next without any changes to the DNA's nucleotide sequence.

\section{"According to the postgenomic concept, the gene is no longer interpreted as a unique functional or molecular entity"}

It is therefore no longer sufficient to just analyze genes to understand the traits to which they are linked. Similarly, the metaphor of a genetic program is not enough to explain an organism, as development results from the activity of many fragmented genes that are activated by environmental stimuli and the expression of which is modulated via epigenetic factors. The meaning and utility of functionalist expressions of "genes for" seem to have dissolved. Genocentrism needs to be replaced by more sophisticated discoursesinspired by self-organization theorieswhereby the organism is a self-organized system that depends on complex interactions between genes and environmental factors. DNA should be regarded as a dynamic data set with spatial and temporal differences, and not as a centrally localized program.

By way of example, Caspi and his collaborators showed that individuals with the short allele of the 5-HTT gene for the serotonin transporter have a higher risk of depression when they experience stressful events in their life [6]. So, in the case of depression, the activity of 5-HTT is modulated on several levels: molecular, depending on 5-HTT alleles; cellular, because the serotonin transporter is involved in synaptic transmission between pre- and postsynaptic neurons; cerebral, because the amygdala and cingulate cortex interact through feedback mechanisms to control the response to stressful environmental conditions; and organismic and environmental, when humans experience stressful situations.

In the same way, the classical molecular "gene concept" becomes problematic in light of epigenetics. DNA expression is controlled by genetic and epigenetic factors-DNA methylation, histone modification, iRNAs, and so on-that are controlled metabolically, through development and environmental factors. So, even if the "classical" gene is related to a given protein, it integrates regulatory and promoter sequences involved in transcription, translation, editing, and epigenetic phenomena in general, since all these elements contribute to the formation of the protein. Moreover, the structural definition of the gene becomes increasingly blurred because it is fragmented in time and space as a molecular particle in the metabolic system.

A $s$ a consequence, the definition of "gene" has had to evolve. Philosophers Paul Griffiths and Karola Stotz, for instance, have proposed the "postgenomic gene" [7]: The classical molecular gene becomes part of a general design reflecting the fact that information is spatially and temporally distributed. The postgenomic gene is "the image of the gene product in
DNA", no matter how the image is broken or distributed and how many regulations are implicated in determining the sequence of proteins. This definition is interesting, but it is only a part of a more global and pluralistic understanding of the gene in the postgenomic era.

\section{"In the political context, blaming nature is easier than blaming nurture"}

The history of genetics has also shown that geneticists are not as objective and rational as they might claim to be. Cultural factors have had a considerable influence. Some postmodern philosophers, notably Foucault and Agamben, stress the importance of power relationships in shaping discourses about the construction of "truth". To put it simply, postmodern philosophy is constituted by a set of critical studies conducted between 1950 and 1980, whose central feature is a disillusionment of modern ideals: autonomy, rationality, scientistic utopia, universal progress. It criticizes philosophical and ideological traditions inherited from the European Enlightenment, such as the quest for rationality and the subsequent "disenchantment" of the world.

The study of the history of genetics and how it was shaped by external social factors is exemplary of this relativistic perspective. Genetics first emerged as a science because it was useful for the ideology of eugenics, rooted in the modern desire to control what man is and what he can become. It seemed possible to avoid the passing on of genes for criminality, "feeblemindedness", sexual deviancy, or amorality to subsequent generations. The genocentric fantasies of the years 1980 to 1990 have similar modern aspects: narrations about humanity's emancipation from its biological condition or about genetics as the ultimate science to understand mankind. These narrations helped to legitimize the study of the "crime chromosome", the "gay gene", the "warrior gene", and the "happiness gene".

A typical postmodern question is therefore: Why study the "gay gene" or the "warrior gene"? Dean Hamer, who is open about his homosexuality, looked for the "gay gene” in 1993 to demonstrate the biological determinism of homosexuality and to counter prejudices against homosexuals. 
New Zealand geneticists discovered a "warrior gene" in the Maori community in 2007, offering a seemingly rational explanation for the endemic problem of violence in Maori culture [8]. It is the same story with the "gangsta gene" in the USA. In the political context, blaming nature is easier than blaming nurture.

$\square$ pigenomics challenged these models. Postgenomics therefore goes beyond the genocentric narrations of modern genetics. Scientifically, it includes studying GxE interactions, epigenetics, proteomics, functional genomics, or interactomics. In all these different domains, the gene is no longer the essential biological unit. Moreover, determinism has become interactive, which means much more than a simple genetic predisposition. It also goes beyond the nature and nurture dichotomy, underlining the deterministic importance of environmental factors and epigenetics. Epistemologically, postgenomics recognizes the plurality of conceptual explanations and it does not seek to unify them. The geneticist Raphael Falk put it as: "Today the gene is [...] a unit, a segment that corresponds to a unit-function, as defined by the individual experimentalist's need. It is neither discrete [...] nor continuous [...] nor does it have a constant location [...], nor a clear cut function [...], not even constant sequences [...] nor defined border lines" [1]. This is not a weakness; on the contrary, the epistemological pluralism is valued for heuristic and pragmatic reasons.

\section{"Postgenomics cannot do without the gene."}

For example, biologists often seem to think in Mendelian terms for quantitative genetics and in molecular terms when they study localized sequences. Continuity exists in spite of deconstruction. The philosopher Lenny Moss commented that the various historical conceptualizations of the gene are essentially a two-way classification, which he calls "gene-P" and "gene-D" [9]. "Gene-P is the expression of a kind of instrumental preformationism [...]. When one speaks of a gene in the sense of Gene-P one simply speaks as if it causes the phenotype." Gene-P does not refer to a molecular sequence or pathway that leads to behavioral phenotypes.
It has more to do with the possibility of studying the transmission of this gene as a predictor of the corresponding phenotype, such as the BRCA genes, and the risk for breast cancer. Gene-P is often linked to a deviation from the normal DNA sequence correlated with the disease or trait. In contrast, gene-D is a transcriptional unitfrom start codon to stop codon-that is independent from phenotypes. For example, the $\mathrm{N}$-CAM gene (neural cell adhesion molecule) is a gene- $\mathrm{D}$ defined by the molecular sequence from which the hundred isoforms of the protein N-CAM are derived. Defining the "gene" is not only a question of conceptual interest. Indeed, the HGP has highlighted the importance of working with precise definitions in order to properly annotate the sequence data. It is obviously necessary to know what a gene is before being able to identify and count them.

The uses of the gene are as numerous as the disciplines that have developed in genetics during the past 100 years. Thus, the epistemologies of research programs are local and specific and the postgenomic era defends the idea that it is by combining, rather than by homogenizing, these different approaches that science advances. Once these plural references are accepted and the meanings have been clarified, the gene becomes a pragmatic tool that enables different experimental systems and research programs.

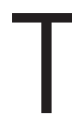
hus, the different epistemological approaches must be understood as complementary in that they offer different ways of understanding a phenomenon. In the postgenomic era, the integrated programs of research multiply the following: genetics and evolutionary biology, genetics and neuroscience, biochemistry, psychology, developmental biology, and so on. The plurality of gene concepts creates a link between these different programs. Postmodernity has denounced the rationalist ideal of science and the inexistence of universal knowledge. Science may be overdetermined by personal motivations, stories, purposes, state of knowledge, etc. One consequence is the existence of plural methodologies and concepts in scientific research-according to research purposes and theoretical hypothesis. Does this mean that subjective wants, group thinking, and other external factors drive science? No. Even if the postmodern approach to science underlines external influences on scientific processes, science is a particular human activity deliberately constructed to minimize subjectivity. Scientists fiercely maintain their attachment to the modern ideal of rationality - maybe not as a clear ontological quality shared by all humans, but certainly as a methodological ideal. For example, Karl Popper's principle of falsifiability is an epistemological reference and it is based on this modern methodological ideal.

Moreover, even if postgenomic biology shows some postmodern aspects, it still follows the narrative of progress. It uses genomic and epigenomic data and tends to correct its theoretical weaknesses and illusions, but it remains in continuity with the older concepts of genetics. Even if epigenetics may sometimes be more important than genetic instruction for development, there is no real paradigmatic shift. Postgenomics cannot do without the gene. It has restricted its scope and explanatory potential and has diluted humankind's modern fantasy of omnipotence, but the gene retains a special place in our epistemological constructions. Finally, disciplinary and conceptual pluralism tends to be based on a pragmatic association of experts, which is typically a modern aspect of knowledge.

$\mathrm{T}$ his essay argues that genocentrism in genetics reflects the modern scientific utopia; knowing genes would have meant understanding human nature, from eugenics to the Human Genome Project. Postgenomics underlines the fact that these gene's eye view narrations are mistaken. Moreover, postgenomics is epistemologically plural. Each explanatory model is characterized by different questions, methods, and assumptions. All these approaches are necessary to embrace and understand all aspects of a phenomenon.

Postgenomics is partly the product of postmodern culture that extends into science: The philosophy of difference takes precedence over universality. There is no one concept of the gene and no one cause of human behaviors. The rational ideal of uniform knowledge -whose genocentrism was an artifact-is a myth. Moreover, pluralistic science depends on pragmatic consensus that everyone is invited to contribute according to their discipline [10]. These are all postmodern and modern aspects of postgenomics. There is no unique biological or environmental cause of violence, "feeblemindedness", or depression, 
partly because there is no single way to be violent or "feebleminded" or depressed and, certainly, no single way of being a geneticist in the postgenomic era.

\section{Acknowledgements}

The author would like to thank the "FONDS DE LA RECHERCHE SCIENTIFIQUE-FNRS" in Belgium and the Université libre de Bruxelles for their support.

\section{Conflict of interest}

The author declares that she has no conflict of interest.

\section{References}

1. Falk R (1986) What is a gene? Stud Hist Phil Sci 17: $133-173$
2. Stotz K, Griffiths PE, Knight R (2004) How biologists conceptualize genes: an empirical study. Stud Hist Philos Biol Biomed Sci 35: $647-673$

3. Kolata G (1993) Scientist at work: Francis S. Collins; Unlocking the secret of the genome. The New York Times, 30 November. http:// www.nytimes.com/1993/11/30/science/ scientist-at-work-francis-s-collins-unlockingthe-secrets-of-the-genome.html

4. Cooper B (2001) Nature, nurture and mental disorder: old concepts in the new millennium. Br J Psychiatry Suppl 178: 91-102

5. Perbal L (2011) Gènes et comportements à l'ère post-génomique. Paris, France: Vrin

6. Caspi A, Sugden K, Moffitt TE, Taylor A, Craig IW, Harrington H, McClay J, Mill J, Martin J,
Braithwaite A et al (2003) Influence of life stress on depression: moderation by a polymorphism in the 5-HTT gene. Science 301: $386-389$

7. Griffiths PE, Stotz K (2006) Genes in the postgenomic era? Theor Med Bioeth 27: 499-521

8. Perbal L (2013) The 'warrior gene' and the Maõri people: the responsibility of the geneticists. Bioethics 27: $382-387$

9. Moss $L$ (2001) Deconstructing the gene and reconstructing molecular developmental systems. In Cycles of Contingency, Developmental Systems and Euolution, Oyama S, Griffiths P, Gray R (eds), pp 85-97. London, UK: MIT Press

10. Hottois G (2005) La science entre valeurs modernes et postmodernité. Paris, France: Vrin 